\title{
Pola Bermukim Masyarakat di Kawasan Rawan Bencana Banjir Kabupaten Luwu Utara
}

\author{
The Community Settlement Pattern in Flood-Prone Areas North Luwu \\ Regency
}

\author{
Suleman Patiung ${ }^{1}$, Batara Surya ${ }^{2}$, Syafri ${ }^{3}$ \\ ${ }^{1}$ Balai Pemantapan Kawasan Hutan Wilayah VII Makasssar \\ 2Program Studi Perencanaan Wilayah dan Kota Program Pascasarjana Universitas Bosowa \\ E-mail: patiungs205@gmail.com
}

Diterima: 01 Februari 2021/Disetujui 12 Juni 2021

\begin{abstract}
Abstrak. Kawasan rawan banjir merupakan suatu ekosistem yang khas yang dapat di lihat dari berbagai sudut pandang. Adanya kondisi seperti ini sangat mempengaruhi pola permukiman masyarakat dalam mendukung pengembangan wilayah di Kabupaten Luwu Utara Provinsi Sulawesi Selatan. Masyarakat Desa Pombakka umumnya mata pencaharian sebagai petani dan nelayan yang menghasilkan sumber sumber pangan bagi kebutuhan hidup masyarakat yang berada di sekitarnya secara khusus dan masyarakat di wilayah Luwu Raya pada umumnya. Pola Permukiman Masyarakat yang dapat menyesuaikan dengan kondisi wilayah yang sering dilanda banjir akibat meluapnya Sungai Rongkong terutama pada musim penghujan mengakibatkan Sebagian permukiman masyarakat terendam banjir. Atas kondisi tersebut masyarakat di Desa Pombakka membuat pola permukiman yang sesuai dengan kondisi banjir tersebut.. Penelitian ini mengkaji mengenai pola permukiman masyarakat di Desa Pombakka yang sering dilanda banjir. Penelitian ini menggunakan teori yang mengkaji Elemen Elemen permukiman (Man, Society, Nature, Network, Shells) yang memberikan kontribusi besar dalam penentuan pola permukiman yang digunakan oleh masyarakat agar sesuai dengan kondisi wilayah sekitar yang sering dilanda banjir.
\end{abstract}

Kata Kunci: Pola Permukiman, Rawan Banjir, Luwu Utara

Abstract. Flood-prone areas are a unique ecosystem that can be seen from various perspectives. The existence of such conditions greatly affects the pattern of community settlements in supporting regional development in North Luwu Regency, South Sulawesi Province. The people of Pombakka Village generally work as farmers and fishermen who produce a source of food for the needs of the people living around them in particular and the people in Luwu Raya area in general. Community Settlement Patterns that can adapt to the conditions of areas that are often hit by flooding due to the overflowing of the Rongkong River, especially during the rainy season, have resulted in some community settlements being flooded. For this condition, people in Pombakka Village make settlement patterns that are in accordance with the flood conditions. This research examines the community settlement patterns in Pombakka Village which are often hit by floods. This research uses a theory that examines the elements of settlement elements (Man, Society, Nature, Network, Shells) which make a major contribution in determining the settlement patterns used by the community to suit the conditions of the surrounding area which is often hit by flooding.

Keywords: Settelement Pattern, Flood-Prone, Luwu Utara

\section{Pendahuluan}

Perumahan dan Permukiman" dinyatakan bahwa permukiman adalah perumahan dengan segala isi dan segala kegiatan yang ada di dalamnya. Jadi, perumahan merupakan wadah fisik, sedangkan permukiman merupakan paduan antara wadah dan isinya yaitu manusia yang hidup bermasyarakat dan berbudaya.

Di dalam Sistem Permukiman, menurut Doxiadis (1968), permukiman adalah paduan antara unsur manusia dan masyarakatnya, alam dan unsur buatan. Semua unsur pembentuk permukiman tersebut saling terkait dan saling mempengaruhi serta saling menentukan satu dengan lainnya. Lingkungan permukiman merupakan sistem yang terdiri dari lima elemen, yaitu : a) Nature (unsur alam), mencakup sumber-sumber daya alam seperti geologi, topografi, hidrologi, tanah, iklim, dan unsur hayati seperti vegetasi dan fauna.

b) Man (manusia), mencakup segala kebutuhan pribadinya, seperti kebutuhan biologis, emosional, nilai-nilai moral, perasaan dan persepsinya.

c) Society (masyarakat), manusia sebagai bagian dari masyarakatnya.

d) Shell (lindungan), tempat dimana manusia sebagai individu dan kelompok melakukan kegiatan dan kehidupannya.

e) Network (jejaring), merupakan sistem alami atau yang dibuat manusia untuk menunjang berfungsinya lingkungan permukimannya, seperti jalan, jaringan air bersih, listrik, telepon, sistem persampahan dan lain sebagainya 
Menurut Turner (1972) "rumah bukan hanya sekedar kata benda melainkan kata kerja yang berkaitan dengan kondisi sosial ekonomi penghuninya".Untuk membedakan kedua pandangan tersebut Turner menggunakan istilah What it does dengan makna kegunaan rumah bagi penghuni dan What it is dengan makna kondisi fisik rumah. Menurut Sumaatmadja (1981) Permukiman atau tempat kediaman penduduk (settlement) diartikan sebagai bagian permukiman yang dihuni manusia dengan segala sarana dan prasarana yang menunjang kehidupan penduduk, yang menjadi satu kesatuan dengan tempat tinggal yang bersangkutan.

Lingkup permukiman mencakup kawasan yang didominasi oleh lingkungan hunian, memiliki fungsi utama sebagai tempat tinggal yang dilengkapi prasarana, sarana lingkungan, untuk tempat kerja terbatas yang mendukung perikehidupan dan penghidupan, sehingga pemukiman dapat berdaya guna dan berhasil guna.

Prasarana yang dilengkapi dalam kawasan hunian merupakan ketentuan yang harus tersedia, yakni fasilitas dasar yang terdiri dari lingkungan fisik alami dan binaan, sehingga memungkinkan lingkungan permukiman dapat berfungsi sebagai mana mestinya. Prasarana tersebut antara lain (1) jaringan jalan untuk mobilitas manusia dan angkutan barang, mencegah perambatan kebakaran serta untuk menciptakan bangunan yang teratur (pola bermukim), (2) jaringan saluran pembuangan air limbah dan tempat pembuangan sampah untuk kesehatan lingkungan, (3) jaringan saluran air hujan untuk drainase dan pencegahan banjir setempat.

Keberadaan suatu permukiman dapat mempengaruhi berkembangnya suatu wilayah, dan sebaliknya kegiatan pembangunan dalam suatu wilayah dapat mempengaruhi berkembangnya permukiman (Buraerah et al, 2020). Permukiman berkaitan secara langsung dengan kehidupan dan harkat hidup manusia, faktor-faktor yang mempengaruhi perkembangan permukiman cukup banyak, antara lain faktor geografis, faktor kependudukan, faktor kelembagaan, faktor swadaya dan peran serta masyarakat, faktor keterjangkauan daya beli, faktor pertanahan, faktor ekonomi dan moneter. Faktor-faktor lain yang berpengaruh terhadap pembangunan perumahan adalah disebabkan oleh perubahan nilai-nilai budaya masyarakat (Surya et al., 2020).

Sedangkan menurut Siswono, ada beberapa faktor yang dapat mempengaruhi perkembangan permukiman yang dapat dilihat dari 9 aspek, antara lain: letak geografis, kependudukan, sarana dan prasarana, ekonomi dan keterjangkauan daya beli, sosial budaya, ilmu pengetahuan dan teknologi, kelembagaan, dan peran serta masyarakat (Yudohusodo, 1991).

Perubahan dari pemanfaatan perumahan menjadi kegiatan komersial (perdagangan dan jasa)menimbulkan perubahan intensitas kegiatan yang berdampak pada tingkat pelayanan prasarana pendukung yang pada awalnya ditujukan untuk pelayanan perumahan (Dani et al., 2017). Penurunan tingkat layanan (level of service) jalan akibat meningkatnya volume lalu lintas dan peningkatan pencemaran udara dan suara serta volume limbah cair merupakan masalah yang kemudian muncul dan mempengaruhi tingkat kenyamanan hunian di Kawasan Pallangga.(Taking, 2000 \& 2015).

Kabupaten Luwu Utara dengan luas sekitar 7.843,57 $\mathrm{Km}^{2}$ terbagi dalam 12 kecamatan yang meliputi 173 desa/kelurahan. Terdapat delapan sungai besar yang mengaliri wilayah Kabupaten Luwu Utara dan sungai terpanjang adalah Sungai Rongkong dengan panjang 108 $\mathrm{km}$ yang melewati tiga kecamatan yaitu Kecamatan Sabbang, Baebunta dan Malangke. Sungai Rongkong masuk dalam DAS Rongkong dengan luas 190.478 ha. Sungai Rongkong memiliki bentuk memanjang. Kemiringan lereng bervariasi dari datar, landai, bergelombang, berbukit sampai bergunung dengan persen kemiringan 0-8, 8-15, 15-25, 25-40, dan $>40 \%$.

Posisi Desa Pombakka yang berada di tepi sungai pada bagian hilir Sungai Rongkong sangat rentan dan rawan terhadap terjadinya bencana banjir terutama pada saat musim penghujan. Banjir yang melanda wilayah Desa Pombakka dapat menggenangi hampir keseluruhan permukiman dan rumah-rumah penduduk dimana tinggi genangan yang terjadi dapat mencapai $1,5 \mathrm{~m}$ (satu setengah meter) dari muka tanah asli. Frekuensi banjir dalam setahun antara dua sampai tiga kali. Seringnya kejadian banjir di desa tersebut tidak serta merta membuat masyarakat meninggalkan atau berpindah dari permukiman tersebut, bahkan rencana program relokasi pemerintah tidak mendapat respon yang baik dari masyarakat setempat.

Terdapat upaya yang dilakukan oleh masyarakat untuk bertahan dari banjir yaitu dengan cara meninggikan rumah mereka, baik dengan menimbun maupun membuat rumah dengan tipe panggung, tetapi tentunya hal ini hanya bisa dilakukan oleh masyarakat yang mempunyai tingkat ekonomi yang tinggi. Bagi masyarakat dengan kondisi ekonomi lemah bentuk antisipasi tersebut tidak mungkin mereka lakukan karena mahalnya biaya. Mereka hanya dapat pasrah bila rumah mereka kebanjiran.

Salah satu fenomena alam yang sering terjadi di Kabupaten Luwu Utara adalah bencana banjir dan tanah longsor yang dapat mengakibatkan kerusakan pada daerah yang ada disekitarnya. Masyarakat pada desa yang terdampak banjir mengungsi ke tempat yang aman, lahan pertanian berupa sawah yang terendam banjir berdampak gagal panen, kerusakan lahan perkebunan, ternak dan lain lain sangat merugikan masyarakat.

Berdasarkan data dari Badan Nasional Penganggulangan Bencana Daerah (BNPBD) Kabupaten Luwu Utara, banjir yang terjadi pada tanggal 29 - 30 April 2019 yang merendam 6 (enam) kecamatan dan 17 desa yang mengakibatkan sebanyak 2.087 KK atau 6.504 jiwa mengungsi ke tempat yang aman. Kecenderungan perubahan iklim di Indonesia juga menyebabkan tingginya Bencana alam yang terjadi (Rasyidi et al,. 2020), terdapat beberapa usaha yang perlu dilakukan untuk menanggulangi bencana longsor seperti mengurangi kemiringan (Sandi et al., 2020; Zahran et al., 2021).

Dari fenomena yang ada seperti yang diuraikan dalam latar belakang maka peneliti terdorong untuk mengkaji pola pola bermukim masyarakat di kawasan rawan banjir serta serta apa yang mempengaruhi sehingga masyarakat tetap bermukim pada kawasan rawan banjir di Desa Kecamatan Malangke Barat Kabupaten Luwu Utara. 


\section{Metode Penelitian}

\section{a. Desain Penelitian}

Penelitian bertujuan untuk merumuskan elemen permukiman yang paling memengaruhi pola permukiman pada lokasi rawan banjir. Penelitian dilakukan dalam dua tahapan yaitu penelitian kepustakaan dan penelitian lapangan. Fokus penelitian adalah pengamatan terhadap karateristik pola permukimaan dengan mengidentifikasi elemen-elemen permukiman yang diduga memengaruhi pola permukiman masyarakat di Desa Pombakka Kecamatan Malangke Barat Kabupaten Luwu Utara yaitu: alam; manusia; masyarakat; bangunan; dan sarana prasarana .

\section{b. Lokasi Penelitian}

Penelitian ini dilakukan di Desa Pombakka Kecamatan Malangke Barat Kabupaten Luwu Utara Provinsi Sulawesi Selatan. Secara geografis, Desa Pombakka berada pada $02^{0} 49^{\prime} 45,35^{\prime \prime}$ s.d. $02^{0} 55^{\prime} 22,90^{\prime \prime}$ LS dan $120^{\circ} 16^{\prime} 01,09^{\prime \prime}$ s.d. $120^{\circ} 19^{\prime} 13,47^{\prime}$ BT. Secara administrasi wilayah pemerintahan, Desa Pombakka berbatasan dengan: Desa Wara di sebelah Utara; Desa Pembuniang di sebelah Timur; Kota Palopo dan Teluk Bone di sebelah Selatan; serta Kecamatan Lamasi Kabupaten Luwu di sebelah Barat.

\section{c. Instrumen Penelitian}

Instrumen penelitian yang digunakan dalam pengumpulan data lapangan berupa kuisioner dan alat perekam. Kuisioner atau daftar pertanyaan dibuat terstruktur yang harus dijawab oleh responden. Data sekunder dalam bentuk data peta, gambar kawasan penelitian, dan data sekunder lain mengenai lokasi penelitian. Alat perekam meliputi kamera, receiver Global Positioning Systems (GPS), dan alat tulis.

\section{d. Jenis dan Sumber Data}

Data yang digunakan berupa data primer dan data sekunder. Data primer merupakan data lapangan hasil observasi dan wawancara. Data sekunder dalam bentuk data peta, gambar kawasan penelitian, dan lainnya. Kerangka acuan kebutuhan data sebagai berikut:

Tabel 1 Data dan Sumber Data

\begin{tabular}{|c|c|c|c|}
\hline Variabel & $\begin{array}{c}\text { Teknik } \\
\text { Pengumpulan } \\
\text { Data }\end{array}$ & Parameter & $\begin{array}{c}\text { Sumber } \\
\text { Data }\end{array}$ \\
\hline $\begin{array}{ll}\text { Mengkaji } & \text { Ekonomi } \\
\text { aktivitas } & \text { Sosial } \\
\text { masyarakat } & \text { Budaya } \\
\text { (ekonomi, sosial, } \\
\text { dan budaya } \\
\text { masyarakat }\end{array}$ & $\begin{array}{l}\text { Kuisioner } \\
\text { Observasi } \\
\text { Wawancara }\end{array}$ & $\begin{array}{l}\text { Sisitim } \\
\text { Aktifitas }\end{array}$ & $\begin{array}{l}\text { Responden } \\
\text { Instansi } \\
\text { Studi } \\
\text { Literatur }\end{array}$ \\
\hline $\begin{array}{l}\text { Menemukan } \\
\text { unsur pembentukNatural } \\
\text { permukiman diMan } \\
\text { kawasan rawanSociety } \\
\text { banjir di DesaShell } \\
\text { Pombakka } \quad \text { Network }\end{array}$ & $\begin{array}{l}\text { Kuisioner } \\
\text { Observasi } \\
\text { Wawancara }\end{array}$ & $\begin{array}{l}\text { Unsur } \\
\text { pembentuk } \\
\text { permukiman }\end{array}$ & $\begin{array}{l}\text { Responden } \\
\text { Instansi } \\
\text { Studi } \\
\text { Literatur }\end{array}$ \\
\hline $\begin{array}{l}\text { Menemukan Pola- Memanjang } \\
\text { permukiman - Menyebar } \\
\text { masyarakat di- Mengelompok } \\
\text { kawasan ranwan } \\
\text { banjir di Desa } \\
\text { Pombakka }\end{array}$ & $\begin{array}{l}\text { Kuisioner } \\
\text { Observasi } \\
\text { Wawancara }\end{array}$ & $\begin{array}{l}\text { Bentuk } \\
\text { permukiman } \\
\text { masyarakat }\end{array}$ & $\begin{array}{l}\text { Responden } \\
\text { Instansi } \\
\text { Studi } \\
\text { Literatur }\end{array}$ \\
\hline
\end{tabular}

Sumber: Kajian Literatur, 2020
Data sekunder diperoleh dari beberapa instansi terkait dan hasil studi literatur.

\section{e. Teknik Pengumpulan Data}

Penentuan teknik pengumpulan data merupakan langkah paling strategis dalam penelitian (Sugiyono, 2008). Pada penelitian ini, data dikumpulkan dengan kombinasi teknik observasi, wawancara, kuisioner, studi dokumentasi, dan studi literatur.

Observasi merupakan suatu proses yang kompleks, tersusun dari berbagai proses biologis dan psikologi, dua yang terpenting adalah proses pengamatan dan ingatan (Hadi dalam Sugiyono, 2012). Observasi dalam penelitian ini dilakukan pada variabel-variabel yakni iklim, geologi, topografi, tanah, air, tumbuh-tumbuhan, hewan, kebutuhan biologi (ruang, udara, air, suhu,dll), nilai moral dan budaya, kepadatan penduduk, strata sosial, budaya, ekonomi, pendidikan, kesehatan dan kesejahteraan (hiburan), hukum, rumah, fasilitas umum (sekolah, rumah sakit, perdagangan, dll), pusat perbelanjaan dan pasar, tempat rekreasi, perkantoran, industri, transportasi, jaringan (sistim air bersih, listrik, jalan, telepon, TV), sarana transportasi, jaringan (drainase, sampah, dan MCK), dan tata letak fisik.

Wawancara menurut Nasution (2003) adalah suatu bentuk komunikasi verbal, merupakan suatu percakapan yang bertujuan untuk memperoleh informasi. Dalam wawancara, pertanyaan dan jawaban diberikan secara verbal. Wawancara dilakukan secara lagsung pada responden. Responden yang dipilih yaitu kepala desa, aparat pemerintahan desa, dan beberapa kalangan masyarakat. Wawancara dilakukan baik secara terstruktur maupun tidak terstruktur (bebas).

Pertanyaan yang dicantumkan dalam kuesioner mengenai variabel penelitian yakni lima elemen permukiman. Penyebaran kuesioner dilakukan terhadap sampel yang merupakan obyek dari penelitian, yaitu masyarakat yang tinggal di kawasan permukiman rawan bencana banjir di Desa Pombakka Kecamatan Malangke Barat. Untuk menentukan jumlah sampel digunakan teknik sampling yaitu merupakan teknik pengambilan sampel (Sugiono, 2010). Penentuan jumlah sampel menggunakan rumus Slovin sebagai berikut:

$$
n=\frac{\mathrm{N}}{1+\mathrm{N}(\mathrm{d})^{2}}
$$

Keterangan :

$$
\begin{array}{ll}
\mathrm{n} & =\text { Jumlah sampel } \\
\mathrm{N} & =\text { Jumlah populasi } \\
\mathrm{d} & =\text { Nilai presisi }
\end{array}
$$

Kepala keluarga di Desa Pombakka sebanyak 410 KK (BPS Kabupaten Luwu Utara, 2017). Meskipun demikian, jumlah rumah yang sering terendam banjir sebanyak $50 \mathrm{KK}$. Nilai presisi ditetapkan $10 \%$ dengan tingkat kepercayaan 95\%. Dengan demikian dari jumlah populasi $(\mathrm{N}=50 \mathrm{KK})$ berdasarkan rumus tersebut maka jumlah sampel yang dibutuhkan sebanyak 33 kepala keluarga.

Studi dokumentasi merupakan pelengkap dari penggunaan metode observasi dan wawancara. Studi dokumentasi diharapkan memberikan dukungan terhadap data yang diperoleh dari wawancara dan observasi seperti 
kegiatan sehari-hari dan foto kegiatan. Dengan demikian, studi dokumentasi sangat penting dalam mempelajari dokumen yang ada seperti dokumen peta desa, data penduduk, dan organisasi desa.

Studi literatur digunakan untuk memperoleh informasi teoritis yang berhubungan dengan masalah yang teliti. Peneliti membaca dan mempelajari informasi yang berkaitan dengan pola bermukim masyarakat di kawasan rawan banjir antara lain dari dan penelitian-penelitian terdahulu yang relevan. Studi literatur ini dimaksudkan untuk memperoleh data teoritis yang dapat mendukung kebenaran data dalam penelitian ini.

\section{f. $\quad$ Teknik Analisis Data}

Analisis data menggunakan teknik analisis statistik deskriptif dan analisis regresi. Analisis deskriptif digunakan untuk mengetahui perilaku masyarakat yang bekerja sebagai determinan pembentukan pola permukiman pada daerah rawan banjir. Analisis tersebut meliputi pengolahan data dan deskripsi elemen permukiman (alam, manusia, masyarakat, bangunan, dan sarana prasarana) yang ada pada lokasi penelitian. Analisis regresi digunakan untuk mengetahui pengaruh pola permukiman terhadap potensi ancaman banjir.

Analisis regresi yang digunakan adalah regresi linier berganda. Analisis regresi berganda menjelaskan hubungan secara linear antara dua atau lebih variabel independen $\left(\mathrm{X}_{1}\right.$, $\left.\mathrm{X}_{2}, \mathrm{X}_{3} \mathrm{X}_{4}, \mathrm{X}_{5}\right)$ dengan variabel dependen (Y). Analisis dimaksudkan untuk: mengetahui arah hubungan antara variabel independen dengan variabel dependen (apakah masing-masing variabel independen berhubungan positif atau negatif); dan untuk memprediksi nilai dari variabel dependen apabila nilai variabel independen mengalami kenaikan atau penurunan. Persamaan regresi linear berganda sebagai berikut:

$$
Y=a+b_{1} X_{1}+b_{2} X_{2}+b_{3} X_{3+} b_{4} X_{4}+b_{5} X_{5}
$$

Keterangan:

$$
\begin{array}{ll}
\mathrm{Y} & \begin{array}{l}
\text { Variabel dependen } \\
\text { diprediksikan) }
\end{array} \\
\mathrm{X}_{1}, \mathrm{X}_{2}, \mathrm{X}_{3}, \mathrm{X}_{4}, \mathrm{X}_{5}, & =\text { Variabel independen } \\
\mathrm{a} & =\text { Konstanta (nilai } \mathrm{Y} \text { apabila } \mathrm{X}_{1}, \mathrm{X}_{2}, \mathrm{X}_{3}, \mathrm{X}_{4} \\
& \mathrm{X}_{5}=0 \text { ) } \\
& =\text { besarnya satuan kenaikan atau penurunan } \\
\mathrm{b}_{1} \mathrm{~b}_{2} \mathrm{~b}_{3} \mathrm{~b}_{4} \mathrm{~b}_{5} & \text { Y dalam satuan, jika } \mathrm{X} \text { ke-n naik/turun satu } \\
& \text { satuannya X lainnya konstan. } \\
& =\text { disebut juga koefisien regresi parsial (partial } \\
\mathrm{b}_{2} \mathrm{~b}_{3} \mathrm{~b}_{4} \mathrm{~b}_{5} & \text { coefficient regression) }
\end{array}
$$

Signifikansi hubungan variabel melalui koefisien regresinya diuji dengan uji statistik. Uji kelayakan model hasil regresi linear berganda meliputi uji keterandalan model (Uji F) dan uji koefisien regresi (Uji t). Analisis regresi linear berganda dan pengujian model dilakukan untuk mencari elemen permukiman yang paling mempengaruhi kondisi pola permukiman pada kawasan rawan bencana banjir di Desa Pombakka Kecamatan Malangke Barat.

\section{Hasil dan Pembahasan}

\subsection{Model Pengaruh Elemen Permukiman} berikut:
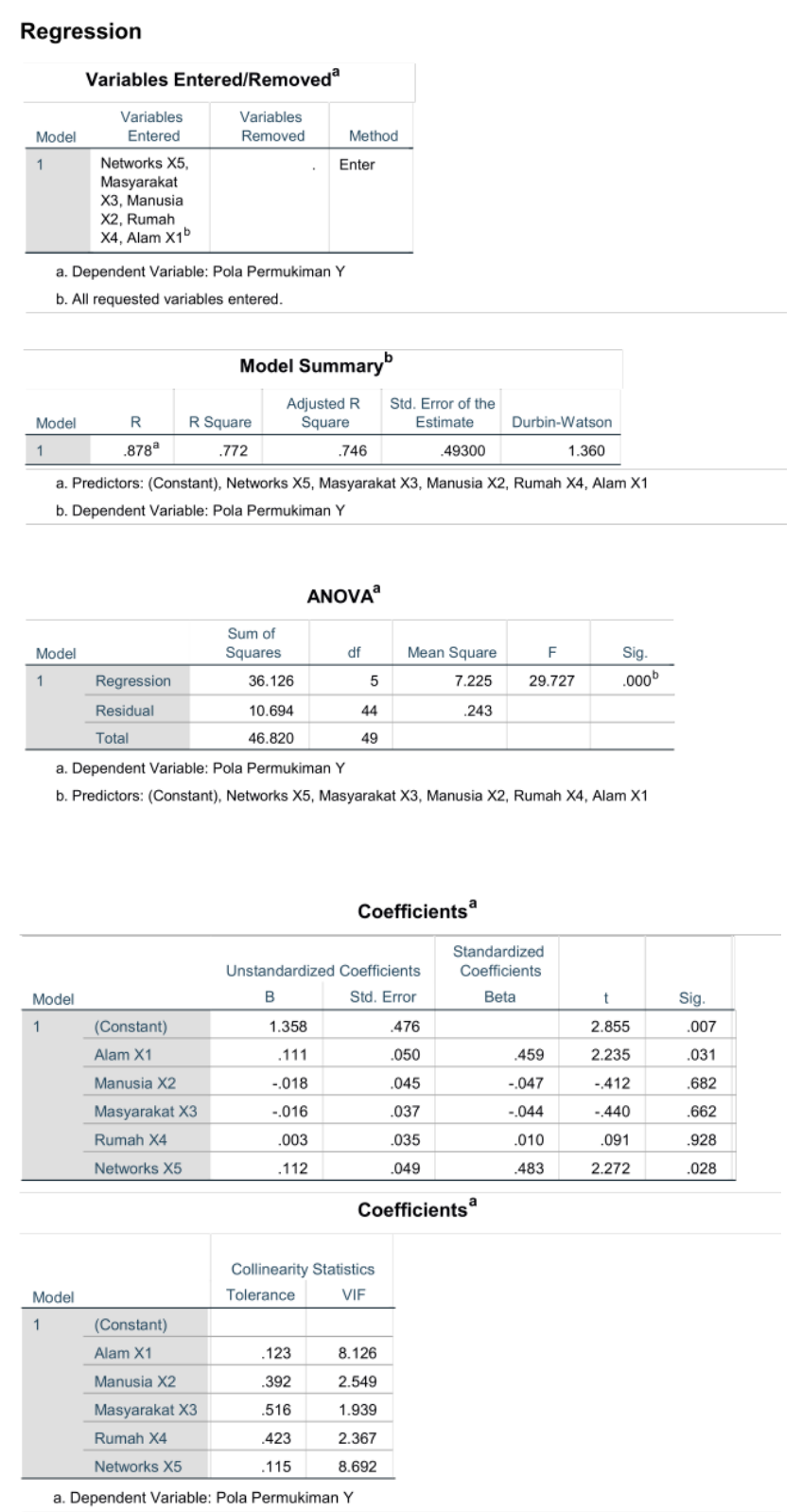

Tingkat pengaruh peubah bebas (independent variabel) menjelaskan peubah tidak bebasnya (dependent variabel) dalam suatu model dapat dilihat pada nilai koefisien determinasi $\left(\mathrm{R}^{2}\right)$. Nilai koefisen determinasi pada interval 0-1 dengan penjelasan bahwa model semakin baik jika mendekati nilai 1 . Nilai $\mathrm{R}^{2}$ model yang dihasilkan dengan menggunakan SPSS adalah sebesar 0,772. Niai $R^{2}$ tersebut menunjukkan bahwa pola permukiman (dependebt variabel) dapat dijelaskan dengan baik oleh kelima elemen permukiman (independent variabel).

Uji keterandalan model (Uji F) menunjukkan bahwa nilai F hitung (29.727) lebih besar dari F tabel $(2,43)$ pada probabilita 0,05. Angka Sig. $(0,000)$ menunjukkan nilai yang lebih kecil daripada probabilita $(0,05)$. Hasil uji $F$ memperlihatkan bahwa $F_{\text {hit }}>F_{\text {tab }}$ dan nilai p atau Sig. $>\alpha$. Dengan demikian dapat disimpulkan bahwa kelima elemen permukiman yang diuji memiliki perbedaan yang nyata (signifikan) dalam pola bermukim masyarakat pada lokasi rawan bencana banjir di Desa Pombakka Kecamatan Malangke Barat Kabupaten Luwu Utara. Perbedaan yang nyata tersebut dijelaskan melalui Uji t. 
Uji koefisien regresi (Uji t) variabel elemen alam (X1) menunjukkan bahwa nilai $t_{\text {hitung }}(2,235)>t_{\text {tabel }}(1,68)$. Nilai Sig. sebesar $0,031<\alpha(0,05)$. Hasil uji tersebut menjelaskan bahwa variabel alam (X1) berpengaruh signifikan terhadap pola permukiman masyarakat dilokasi rawan banjir $(\mathrm{Y})$.

Uji koefisien regresi (Uji t) variabel elemen manusia (X2) menunjukkan bahwa nilai $t_{\text {hitung }}(0,412)<t_{\text {tabel }}(1,68)$. Nilai Sig. sebesar $0,682>\alpha(0,05)$. Hasil uji tersebut menjelaskan bahwa variabel manusia (X2) tidak berpengaruh signifikan terhadap pola permukiman masyarakat dilokasi rawan banjir (Y).

Uji koefisien regresi $(\mathrm{Uji} t)$ variabel elemen masyarakat (X3) menunjukkan bahwa nilai $t_{\text {hitung }}(0,440)<$ $t_{\text {tabel }}(1,68)$. Nilai Sig. sebesar $0,662>\alpha(0,05)$. Hasil uji tersebut menjelaskan bahwa variabel masyarakat (X3) tidak berpengaruh signifikan terhadap pola permukiman masyarakat dilokasi rawan banjir (Y).

Uji koefisien regresi (Uji t) variabel elemen rumah (X4) menunjukkan bahwa nilai $t_{\text {hitung }}(0,091)<t_{\text {tabel }}(1,68)$. Nilai Sig. sebesar $0,928>\alpha(0,05)$. Hasil uji tersebut menjelaskan bahwa variabel rumah (X4) tidak berpengaruh signifikan terhadap pola permukiman masyarakat dilokasi rawan banjir (Y).

Uji koefisien regresi (Uji t) variabel elemen sarana dan prasarana atau jaringan/network (X5) menunjukkan bahwa nilai $t_{\text {hitung }}(2,272)>t_{\text {tabel }}(1,68)$. Nilai Sig. sebesar $0,028<\alpha(0,05)$. Hasil uji tersebut menjelaskan bahwa variabel elemen sarana dan prasarana atau jaringan/network (X5) berpengaruh signifikan terhadap pola permukiman masyarakat dilokasi rawan banjir (Y).

Nilai koefisien regresi elemen alam (X1) sebesar 2,238 (bernilai positif). Nilai koefisien regresi yang positif menjelaskan bahwa pengaruh yang ada bersifat selaras (bukan berkebalikan). Dengan kata lain, maknanya adalah bahwa jika semakin baik kondisi dan karakteristik alam pada Desa Pombakka maka akan berpengaruh positif pada pola permukiman dilokasi rawan bencana banjir.

Nilai koefisien regresi elemen sarana dan prasarana (X5) sebesar 2,272 (bernilai positif). Nilai tersebut menandakan bahwa jika sarana dan prasarana yang tersedia dilokasi dalam kondisi buruk atau tidak berfungsi dengan baik maka akan berpengaruh negatif terhadap pola permukiman masyarakat di lokasi rawan bencana banjir.

Untuk menguji korelasi antar kelima variabel independent, dilakukan uji collinearity. Uji tersebut ditentukan oleh nilai collinearty tollerance (tidak ada korelasi jika nilai > 0,1) dan nilai variance inflation factor/VIF (tidak ada korelasi jika nilai < 10). Hasil uji collineariy dengan menggunakan SPPS menunjukkan bahwa kelima variebel independent tersebut (X1-X5) memiliki nilai collinearity tollerance berturut-turut 0,123 ; 0,$392 ; 0,516 ; 0,423$; dan 0,115 . Nilai VIF untuk X1-X5 berturut-turut 8,$126 ; 5,549 ; 1,939 ; 2,367$; dan 8,692 .

Hasil pengujian tersebut menunjukkan bahwa kelima variabel independent tidak memiliki hubungan yang erat atau tidak terdapat gejala hubungan linear antara kelima elemen. Hasil uji tersebut menunjukkan bahwa ntara elemen alam (X1) dengan elemen jaringan/network (X5) yang terbukti dapat menjelaskan pola bermukim masyarakat di daerah rawan bajir tidak memiliki hubungan yang erat. Dengan kata lain, kedua elemen tersebut dapat digunakan dengan sangat baik untuk menjelaskan pola bermukim masyarakat pada daerah rawan longsor di Desa Pombakka Kecamatan Malangke Barat Kabupaten Luwu Utara Provinsi Sulawesi Selatan.

\subsection{Elemen Permukiman}

Hasil yang diperoleh dari deskripsi elemen permukiman pada masayarakat yang bermukim pada daerah rawa banjir di Desa Pombakka Kecamatan Malangke Barat Kabupaten Luwu Utara Provinsi Sulawesi Selatan sebagai berikut:

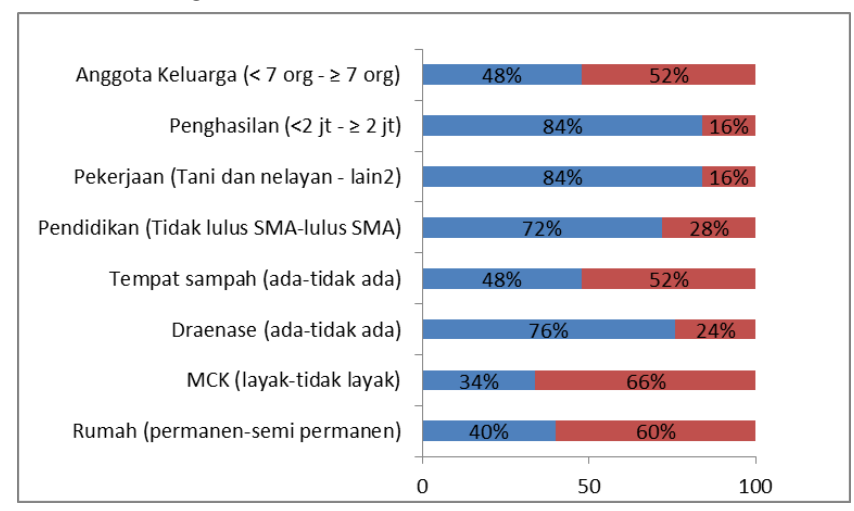

Gambar 1 Kondisi Elemen Permukiman Masyarakat Desa Pombakka

Analisa kondisi fisik rumah dan permukiman (shells) meliputi penguasaan tempat tinggal dan kondisi fisik bangunan. Masyarakat pada awalnya memperoleh lahan dari pemerintah melalui program transmigrasi pada akhir tahun 1970. Saat ini tidak terdapat permukiman baru karena keterbatasan lokasi. Beberapa penguasaan tanah kemudian berpindah melalui transaksi jual beli. Kondisi fisik rumah beragam. Perbedaan kondisi rumah tersebut menunjukkan tingkat ekonomi masyarakat yang bervariasi. Secara keseluruhan, sebagian besar masyarakat berada pada kondisi yang berkekurangan $(60 \%)$. Sebagian kecil $(40 \%)$ memiliki rumah yang permanen.

Analisa kondisi fasilitas dan perlengkapan sarana permukiman (network) dilakukan pada fasilitas tempat mandi dan baung air besar (MCK). Kondisi pada variabel ini cukup buruk dengan hanya 34\% kepala keluarga yang memiliki fasilitas MCK di dalam atau di sekitar rumah. Sebagian besar masyarakat (66\%) masih menggunakan MCK umum atau sungai. Terdapat 2 (dua) unit MCK umum yang disediakan oleh Pemerintah Desa Pombakka. Kondisi MCK umum tersebut tidak terawat dengan baik hingga tidak dapat digunakan sebagaimana mestinya.

Kondisi lingkungan rumah tangga (nature) yang dianalisis meliputi cara pembuangan limbah (sistem draenase) lingkungan dan sarana pembuangan sampah. Sistem draenase sangat buruk dengan sebanyak $76 \%$ responden tidak memiliki saluran draenase yang berfungsi. Saluran yang ada sangat kecil dan tidak dapat berfungsi dengan baik. Responden lainnya (24\%) memiliki draenase namun juga tidak berfungsi karena penyalahgunaan saluran (tempat pembuangan sampah). Sampah masyarakat tidak dikelola dengan baik. Pemerintah desa menyediakan tempat pembuangan sementara namun lokasinya jauh dari rumah 
responden. Tempat pembuangan sampah oleh responden pada dasarnya adalah sungai. Sebanyak $52 \%$ responden membuang sampah rumah tangganya langsung ke sungai atau saluran air. Responden lainnya (48\%) menyediakan tong sampah kecil di rumah untuk sementara yang jika sudah penuh akan dibuang ke sungai.

Kapasitas ekonomi masyarakat (man) yang dianalisis meliputi tingkat pendidikan, mata pencaharian, dan hasil usaha masyarakat. Tingkat pendidikan responden rendah dengan hanya $10 \%$ yang tamat perguruan tinggi, $18 \%$ lulusan SMU, 26\% yang hanya sampai pada pendidikan SMP, $32 \%$ yang tamatan SD, dan $14 \%$ tidak tamat SD. Kebanyakan remaja putus sekolah karena membantu orang tua dalam bekerja sehari-hari. Sebagian besar masyarakat memiliki mata pencaharian sebagai petani $(52 \%)$. Petani yang dimaksud berupa petani tambak dan petani lahan kering. Kelompok berikutnya adalah nelayan (32\%), wiraswasta (8\%), ASN (6\%), dan tukang (2\%). Pendapatan hasil usaha masyarakat dikelomppokkan dalam pendapatan per bulan kurang dari Rp. 500.000 sebanyak $18 \%$, Rp.500.000 s.d. Rp.1.000.000 (30\%), Rp.1.000.000 s.d. Rp.1.500.000 (18\%), Rp.1.500.000 s.d. Rp.2.000.000 (18\%), dan pendapatan per bulan lebih dari Rp.2.000.000 $(16 \%)$.

Analisa kondisi sosial masyarakat (society) dilakukan pada organisasi sosial dan keagamaan dan jumlah anggota keluarga. Masyakat menganut 3 (tiga) keyakinan yaitu Islam (80\%), Protestan (14\%), dan Katolik (6\%). Kehidupan sosial masyarakat yang bermukim disekitar lokasi rawan banjir sangat harmonis. Keharmonisan tersebut terpelihara dan tercermin dalam hubungan kekeluargaan sehari-hari dan saling memberi bantuan bagi sesama yang membutuhkan. Di samping itu, sistem gotong royong sangat kental terlihat seperti pada perbaikan permukiman atau pada acara pernikahan. Keharmonisan dan kerukunan anggota masyarakat tersebut dapat menjadi modal masyarakat untuk mencapai kehidupan yang lebih baik. Dari aspek jumlah anggota keluarga, sebagian besar merupakan keluarga besar. Keluarga besar di Desa Pombakka merupakan suatu keuntungan dalam hal ketersediaan tenaga kerja dalam mengelola lahan garapan. Sebanyak 52\% responden memiliki anggota keluarga 7-10 orang, hanya $6 \%$ responden yang memiliki anggota keluarga 3 orang. Responden yang lainnya (42\%) memiliki anggota keluarga 4 s.d. 6 orang.

\section{Kesimpulan dan Saran}

Hasil penelitian dapat disimpulkan bahwa elemen permukiman yang mampu menjelaskan pola bermukim masyarakat pada daerah rawan banjir di Desa Pombakka Kecamatan Malangke Barat Kabupaten Luwu Utara adalah elemen alam (X1) dan elemen jaringan/network (X5). Elemen permukiman lainnya yaitu manusia (X2), masyarakat (X3), dan rumah (X4) tidak dapat menjelaskan pola bermukim pada daerah rawan banjir di Desa Pombakka Kecamatan Malangke Barat Kabupaten Luwu Utara.

\section{Daftar Pustaka}

Buraerah, M. F., Rasyidi, E. S., \& Sandi, R. (2020). Pemetaan Perubahan Penggunaan Lahan Di Wilayah Kabupaten Takalar Tahun 1999-2019 Menggunakan Sistem Informasi Geografis. Ecosystem, 20(1).

Dani, E. T., Sitorus, S. R. P., \& Munibah, K. (2017). Analisis Penggunaan Lahan dan Arahan Pengendalian Pemanfaatan Ruang Di Kabupaten Bogor. TATALOKA, 19(1), 40 https://doi.org/10.14710/tataloka.19.1.40-52

Doxiadis, Constantinos A. 1968. Ekistics An Introduction To The Science Of Human Settlements. London: Hutchinson Of London.

Hanif Zahran, M., Salim, A., \& Budiharto, T. (2021). Arahan Mitigasi Bencana Kawasan Rawan Longsor Di Kabupaten Sinjai. Journal of Urban Planning Studies, 1(2), 196-203. https://doi.org/10.35965/jups.v1i2.37

MI, Taking. (2000). Studi Konsolidasi Lahan Perkotaan KelurahanTetebatu KecamatanPallangga Kota Sungguminasa.Universitas 45 Makassar.

MI, Taking. (2015). Perubahan Pemanfaatan Lahan dan Implikasinya dalam Pengendaliaan Ruang di Kawasan Perkotaan Sungguminasa. Universitas Bosowa.

Nasution. (2003). Metode Penelitian Naturalistik Kualitatif. Bandung: Tarsito.

Rasyidi, E. S., Sandi, R., \& Buraerah, M. F. (2020) Monitoring Perubahan Suhu Ibu Kota Negara Tahun 1993-2019 Menggunakan Citra Satelit Landsat (Studi Kasus: Jakarta, Singapura, Kuala Lumpur Dan Bangkok). Ecosystem, 20(1), 50-58.

Sugiyono. 2008. Metode Penelitian Kuantitatif Kualitatif dan R\&D. Bandung : Alfabeta.

Sugiyono. 2010. Metode Penelitian Pendidikan Pendekatan Kuantitatif, kualitatif, dan R\&D. Bandung: Alfabeta.

Sugiyono. 2012. Metode Penelitian Kuantitatif Kualitatif dan R\&B. Bandung: Alfabeta.

Sumaatmadja, Nursid. 1981. Studi Geografi Suatu Pendekatan dan Analisa Keruangan. Bandung : Alumni.

Surya, B., Hadijah, H., Suriani, S., Baharuddin, B., Fitriyah, A. T., Menne, F., \& Rasyidi, E. S. (2020). Spatial Transformation of a New City in 20062020: Perspectives on the Spatial Dynamics, Environmental Quality Degradation, and Socioeconomic Sustainability of Local Communities in Makassar City, Indonesia. Land, 9(9), 324.

Turner, John FC. 1972. Freedom to Build, Dweller Control of the Housing Process, The Macmillan Company, New York.

Undang-Undang Nomor 4 Tahun 1992 tentang "Perumahan dan Permukiman.

Yudohusodo, Siswono. 1991. Rumah Untuk Seluruh Rakyat, Direktorat Jendral Cipta Karya, Jakarta 
Yudohusodo, Siswono, 1991, Tumbuhnya PermukimanPermukiman Liar di Kawasan Perkotaan, JIIS. Nomor. 1. 